\title{
ENTREPRENEURSHIP FOR DEVELOPING SMALL AND MEDIUM-SCALE FARMERS IN AGRICULTURAL CLUSTER
}

\author{
Silfia \\ silfiasukri@gmail.com \\ Helmi \\ Melinda Noer \\ Henmaidi \\ Andalas University \\ Limau Manis, Pauh, Padang, Sumatra Barat 25175 \\ received: 11/5/20; revised: 22/10/20; approved: 14/12/20
}

\begin{abstract}
The entrepreneurship possesses the energy to generate innovation and improvement of agricultural clusters. However, it somehow has yet been successful to reach marginalized groups including Small and Medium Enterprises (SMEs) in agricultural clusters. The research questions to be addressed are thus: (1) how public policy at both national and regional levels contribute to entrepreneurship capacity-building in developing agricultural cluster in order to achieve SMEs empowerment. (2) Empiric actuality of entrepreneurship in agricultural cluster development. The research is a qualitative-descriptive research, case study on agricultural cluster at Subdistrict Lembah Gumanti of Solok Regency in the province of West Sumatra. Research result indicates that entrepreneurship policy has indeed yet at its best in the development of SME-based agricultural clusters due to the fact that entrepreneurial policy in agricultural clusters is still dominated by personal/private and corporation-based entrepreneurship.
\end{abstract}

Keywords: regional policy; collective action; small farming; agri-bussiness; sinergy

\section{INTRODUCTION}

Entrepreneurship has long drawn global attention as it possesses the drive to generate innovation. Some of the roles played by entrepreneurship are improving competitiveness, contributing to the achievement of prosperity, dropping unemployment rate, and improving the economic development and regional growth. In agricultural development, entrepreneurship played its roles as it is one of the keys to the success of the efficiency in the use of technology, seizure of opportunity, management of agricultural business, improvement of agricultural operations, development of agricultural various functions, as well as strengthening primary sectors and growth of secondary and tertiary sectors (Shane and Venkataraman 2000; Yanya,et al. 2013; Andreopoulou et al. 2014; Baranyi and Taralik 2015; Darmadji 2016; Harpa et al. 2016; Hassink et.al. 2016). The development of agricultural clusters requires the roles of entrepreneurship as it would not succeed had it only rely on the decency of nonprofit organizations act of philantropy and governmental program. It will not be efficient due to the limit of budgets and political behaviour (Yunus 2008; Dhewanto, 2013; Firdaus
2014) The active roles that entrepreneurship played have improved agricultural clusters and thus, numerous countries created entrepreneurial policy to develop agricultural clusters (Sefrioui 1999; Ikatrinasari 2010; Malek et.al. 2009; Ahmad et al. 2014; Fajzrakhmanov et al. 2013; Balabanova et.al. 2014; Ashari 2016; Malek 2017).

Entrepreneurial policy is one of the elements of public policy. One of the proposed definitions of public policy describes that it is a series of certain actions or regulations aimed at the community. Public policy as an output of a government is aimed to achieve an outcome i.e. the expected condition of society's life. If the expected outcome is not achieved then the public policy has not been effective (Soewargo 2009; Wibawa 1994; Agustino 2016; Dye 2017). In 2014 the World Bank requires governments to implement effective public policy. Entrepreneurial policy in agricultural clusters pertains to the economic and physical diversity that are functionally related (Bappenas 2004). In agricultural cluster there are small-scale agricultural (SMEs) operations and their existence are massive. Throughout Asia the presence of these smal-scale agricultural operations reached a percentage of $85 \%$ 
and in Indonesia, they even reach a figure of $88 \%$. They play imperative roles yet they constantly are met with various limitations and small income (Thapa 2010; Lowder et.al. 2016; BPS 2013; 2018).

This research starts from the issue why entrepreneurial policy has not been able to develop SME-based agricultural clusters at its best. The research questions are thus: (1) how public policy at both national and regional levels contribute to entrepreneurship capacity-building in developing agricultural cluster in order to achieve SMEs empowerment. (2) Empiric actuality of entrepreneurship in agricultural cluster development. The results of this research are expected to be a contribution of knowledge and become some of the concerns in improving and strengthening public policies both nationally and locally.

According to Yanya et al. (2013) and Buang and Suryandari (2009), entrepreneurship has indeed been at its best in reaching the marginalized groups including SMEs in agricultural clusters due to the incompatible approach. Scientifically the implementation and public policy are dominated by the forms of individual and corporation entrepreneurship. Individual entrepreneurship is centered around diligent individuals in creating and seizing opportunities meanwhile corporation entrepreneurship is oriented to the improvement of coorporation values and performance. The characteristics of both individual and corporation entrepreneurship are oriented to the interests of individuals or a group of capital owners pertaining to the capital they manage or profit-oriented (Shane and Venkataraman 2000; Belousova et.al. 2010); meanwhile entrepreneurship to develop agricultural clusters requires the support of local systems. It is a set of common factors, both common problems and common effort (Martin 2003; Kitson et.al. 2004; Mansfeld and Antrosio 2009). Entrepreneurship for SME-based agricultural clusters requires communal strength that synergizes with the entrepreneurship that is based on social and environmental sensibility. This is known as communal entrepreneurship (Jennings et al. 2013; Kuura et. al. 2014; Dahalan et.al. 2013; Varady et.al. 2015; Fortunato and Alter. 2003; 2016).

Entrepreneurial policy in Indonesia is still limited and thus requires deeper exploration (Mirzanti et.al.2015; Darmadji 2016). Communal entrepreneurship still needs to be built and developed (Tohani 2017). Yet, communal entrepreneurship empirically grows and develops to influence the development of agricultural clusters. Studies on communal entrepreneurship in agricultural clusters may serve as scientific contribution. Based on literature reviews from references published between $1998-2020$ it is evident that there has been no publication on entrepreneurial policy that reaches communal entrepreneurship in SME-based agricultural clusters. Relatively, there have been very few studies on social and communal entrepreneurship and most are still in conceptual level (Jennings et al. 2013; Sekliuckiene and Kisielius 2015; Parwez 2017; Mandrysz 2020).

\section{METHODS}

The research is designed to identify national policy related to entrepreneurship in agricultural clusters. The public policy includes the 1945 Constitution, the Stipulations of the People's Deliberative Assembly (Majelis Permusyawaratan Rakyat, MPR), Acts, government regulations, presidential decrees, ministerial decrees, decrees of director generals, and regional ordinances. The research is descriptive-qualitative in nature. Two methods are combined during in the accomplishment of the research, i.e. (1) survey on literatures: the process of placing, acquiring, and evaluating research literatures such as journals, articles, documents, or visual materials pertaining public policy; (2) case study in agricultural clusters at Lembah Gumanti Subdistrict in Solok Regency, Province of West Sumatra. In 2014 the Ministry of Agriculture appreciated the potentials of this region as a national prospective area. This was performed in order to obtain social, economic, political, and environmental facts of a group or area as a spot of entrepreneurial activities in agricultural clusters. Data gathering was conducted through in-depth interview towards key informers as well as observation to strengthen data so it reflected factual condition that covered activities, interaction and physical achievements.

The community at Lembah Gumanti are dominantly actors of agricultural SMEs ranging from small farming to its supporting sectors such as trade, transportation, and warehousing. The survey on the population of the farmer groups conducted with the assistance of the subdistrict's instructor as key informer during February through March 2018 indicated that there are 141 farmer groups. The selection towards the groups was conducted purposively based on the prominence of entrepreneurial management. Data analysis covered (a) data reduction through core abstaction, summarization and focusing on pattern. Data reduction took place continuously as the research progressed; (b) data presentation was conducted by classifying data as answers to questions which is then presented in the form of matrix or tables; (c) drawing of conclusion based on findings and analysis guided by research questions and occurring relations which is then put forth as conclusion.

\section{RESULTS}

The analysis towards entrepreneurial policy is the identification to a series of certain regulations or actions as an attempt to cope with a condition that is dissatisfying to the community through system and deployment of resources (Wibawa 1994; Agustino 2016; Dye 2017). The support of national and local public policy towards entrepreneurship in agricultural clusters was reviewed based on the formal structure of public policy in Indonesia. Based on the stipulation of 
the Indonesian MPR No. XX of 1996 on the Hierarchy of Indonesian Legal Codes the hierarchy is as follows: the 1945 Constitution, the Stipulations of the MPR, Acts, Government Regulations, Presidential Decrees, Ministerial Decrees, and Decrees of Director Generals. In regional level public policy is formulated into Ordinances.

Entrepreneurial policy in agricultural clusters is identified in the national policies on agricultural clusters, and entrepreneurship. Figure 1 and Table 1 indicate public policies related to agricultural clusters such as Law No. 26 of 2007 on Spatial Management, Law No. 19 of 2013 on the Protection and Empowerment of Farmers, Ministerial Decree No. 50/Permentan/ CT.140/8/2012 on the Development of Agricultural Clusters. Entrepreneurial policy is regulated under Law No. 20 of 2009 on Small and Medium Enterprise, Law No. 32 of 2004 on Regional Government, Village Act (Law No. 6 of 2014), Government Regulation (Peraturan Pemerintah, PP) No 71 of 2005 on Village, Decree of the Minister of Home Affairs No. 39 of 2010 on its Article 12 on Village-owned Enterprises, and Presidential Decree No. 27 of 2013 on the Development of Entrepreneurship Incubator.

Entrepreneurship in West Sumatra is contextually revealed through a case study in the agricultural cluster of Lembah Gumanti Subdistrict in Solok Regency, Province of West Sumatra. In 2014 the Ministry of Agriculture named Solok Regency as a prospective area where the Lembah Gumanti Subdistrict stood out as production centre. However, the intensification of development is a necessity as the agricultural cluster possesses some shortcomings; program integration and sustainability (Helmi et al. 2019).

Lembah Gumanti subdistrict poses great potential in the development of entrepreneurship. The community in the area is mainly agricultural which stood at the figure of $77.55 \%$; mainly small-scale farming (BPS 2020). Entrepreneurial activities of the area are supported by the communal force in two forms. The first one was born from the local genius that was then informally instituted which served as the funding for farming. The second form is the existence of communal synergy with social entrepreneurship in order to access the management costumary communal resources (land) of nagari (smallest governmental administrative unit that exists only in West Sumatra).

The community at Lembah Gumanti Subdistrict owns their own drive in supporting their entrepreneurship activities which they call Handel. It is a socio-cultural and economic institution that serves as a social force as well as the management of savings and loans. The institution is a group of people and money with organizational structure but no legal standings and its membership is in the form of modified cooperation and arisan (a kind of lottery club) - a regular social gathering. Members are bound to pay individual contribution and saving. They are also required to take loans which will be distributed in turns to each member (Fig. 2). The Handel system has existed since the people in the area ran rice farming (in 1970) and even until they expanded to horticulture farming in 1980 up to present. Handel is managed by means of unwritten local genius but deeply rooted in the community of the area. Handel has been playing its roles in the entrepreneurship of the area as the loan to members are then used as source of funding for farming, trading, or even just for making ends meet.

Local and public policies can be synergized in the utilization of costumary communal land of the nagari by means of collective effort of social and communal entrepreneurship. Access to the land is obtained by the Solok Radjo Cooperative and Rimbo Agrobisnis farm group.

Solok Radjo is a cooperative that focuses on the development of Arabica coffee in West Sumatra. The Solok Radjo Cooperative was established in 2014 as a medium of change among Arabica farmers. It was registered as a legal entity that has complied with Law No. 25 of 1992 on Cooperatives. The cooperative has been an institution that covers farmers in threee subdistricts i.e. Danau Kembar, Lembah Gumanti and Lembang Jaya in Solok Regency. It assists the economic advancement of locals by purchasing the crops from the surrounding communities at decent even better price than that offered by middlemen or collecting traders. According to (Putri et al. 2018), Solok Radjo Cooperative did make change.

One of the changes made is in terms of coping with the limitation of farm area as most members possess between 0.5 to 1 hectare of farm area. This does not adequately capable of meeting the needs of market and investors. The cooperative owns the support from the nagari government through the local policy that supports the program of the cooperative. Since 2018 the nagari government provided access to the costumary communal land of the nagari so the cooperative can manage the land for coffee farming. The management of the 320-hectare nagari asset provided assistance in coping with limitation of farming areas and, at the same time, with the environmental problem; the previously vacant, mountainous area of the nagari asset is now planted with coffee. The public policy for the utilization of the nagari asset is based on Article 18B Sentence (2) of The 1945 Constitution which stipulates that the State shall acknowledge and respect the units of costumary law-based society along with their traditional rights insofar they are still in existence and in conformity with the development of society and the principle of the Unitary State of the Republic of Indonesia, as regulated by law. Moreover, Law No. 5 of 1960 of Fundamentals of Agrarian Principles acknowledges the aforementioned phrase insofar they are still in existence.

Costumary-based right is a series of authority and duties of a costumary-based community pertaining 
land in their surroundings. Regional Ordinance of West Sumatra No. 16 of 2008 on Costumary-based Assets and Its Utilizations stipulates that tanah ulayat nagari (costumary-based communal land) is a land including the natural resources within that is occupied by the Ninik Mamak (respected traditional elders) of Kerapatan Adat Nagari/KAN (Nagari Deliberative Council) and shall be utilized to the greatest extent to serve the interests of the nagari community, meanwhile the nagari government acts as the party that regulates its utilization. The utilization may include the utilization by the public, for the benefit of legal entity(ies) and individuals as well as investors. This policy supports entrepreneurship in agricultural clusters and simultaneously boosts the attempt to improve the forest areas of nagari and areal sustainability. The support to access the asset provides strategic roles to the Solok Radjo Cooperative in developing agricultural cluster that contends with small-scale farming and welcomes investors as partners.

Access to the utilization of costumary communal land is also granted to Rimbo Agribisnis Farm Group. The group was established in 2010 covering 30 members. The membership of the group does not only include farmers but also students of the region. This group is partnered with the Center for Transfer of Technology of Andalas University and together they become incubator of business in fostering the entrepreneurship of students. The nagari government provides support by granting the right to manage costumary communal land by planting white trees. The pro-entrepreneurship policy contributes to the reforestation of the area.

\section{DISCUSSION}

The support towards entrepreneurship and development of agricultural clusters has indeed been enforced in many countries around the globe (Sefrioui 1999; Malek et al. 2009; Malek 2017; Ikatrinasari 2010; Ahmad et al. 2014; Fajzrakhmanov et al. 2013; Balabanova et al. 2014; Ashari 2016) However, the support does not necessarily stand alongside the small-scale farming in agricultural clusters. Countries dominated by small-scale farming requires the synergy of entrepreneurship and community. Unfortunately, entrepreneurial policies tend to support individual and corporate entrepreneurship. These two inevitably tend to serve the interests of some individuals or a group of capital owners in relations to the capital they manage, or in other words, profit-oriented (Shane and Venkataraman 2000; Buang and Suryandari 2009; Belousova et al. 2010; Yanya et al. 2013; Kuura et al. 2014).

Entrepreneurial policy in agricultural clusters in Indonesia is identified through the national policy on agricultural clusters as well as the national policy on entrepreneurship. The policy on agricultural clusters has contained the implementation of entrepreneurship for actors of enterprises in agricultural clusters covering productivity, value-added improvement, marketing network, level of income, labour inclusion, complex access, and development of strong entrepreneurship that does not rely on governmental fundings. The roles of entrepreneurship is implemented in the form of stateowned and region-owned enterprises, foreign and local investments, cooperatives etc affect the institutions and supporting policies to foster entrepreneurship.

Entrepreneurial policy in Indonesia is implemented on three levels, i.e. macro, mezzo, and macro. The Micro Level is oriented to the creation of entrepreneurs through programs of technical and business training, apprenticeship, and other efforst to achieve entrepreneurs' capacity-building. The Mezzo Level is directed to enterprises and entrepreneur community that has yet received support. Meanwhile the Macro Level takes the form of intervention, national movement, and soft loans. Entrepreneurial policy at the micro level mainly focuses on the development of skills, opportunities, and motivation. Skills cover managerial, business and technical skills; opportunities include market access and access to funding; motivation cover incubation or guidance, role models, and knowledge exposure. Meanwhile, at the macro level is government interventions that focus on venture model, entrepreneurship education, entrepreneurship culture, entrepreneurship infrastructure and training for trainers (Mirzanti et al. 2015). Likewise, the social entrepreneurship is created in the form of corporate social and environmental responsibilities (CSR) for companies and investors.

There are some weaknesses of the existing policies, some of them are: (a) Policies have not bolstered the synergy between entrepreneurship and community to achieve productivity improvement, value-added, supply chain management, innovation and access; (b) SME-based farming actors are weak in terms of access to financing, meanwhile these actors are in extensive number in agricultural clusters. This hindrance occurs due to the limitation of the actors to meet bankability standard as well as their fright to be held liable to any risk concerning loans; (c) Public policy is still a topdown framework. Despite submission of aspiration from the lowest governmental administrative unit, public policy is conceptually the result of the ratification of international conventions, national-level regulations all the way down to the level of regency; (d) Feeble regulation on the implementation, control, strategy, and limited availability and capacity of human resources.

Those weaknesses are then worsened by the limited lack of commitment from the government, business fields and society that can be reflected from the limited allocation of fund/budget. Likewise, community' social capital is not fully accommodated, and leadership of formal and non formal institutions are barely responsive to the planning and management of local resources as the economic basis in developing people's economy, 
as well as the lack in the roles of local dignitaries. The policies are mostly still in the form of unimplemented commitments and they have not driven the construction of local policy pushes resulted from the exploration on the social-economic condition of the community which is capable of being the source of solution to the social issues. The synergy of various quarters is imperative in the growing and developing communal entrepreneurship. Public policies as the effort to support entrepreneurship in agricultural clusters are still in the form of consideration and still lack in terms of implementation references resulting in an implementation that fails to achieve targeted objectives.

Policy on social entrepreneurship is far from adequate because it is only dependent to public policies on CSR. In fact, CSR is another drive to the social entrepreneurship that can be developed in agricultural clusters as well as the small-scale enterprises in the area. CSR is actually a public policy that fosters good objectives. However, in terms of implementation CSR has a downside where companies would perform good activities to the community only in order to achieve positive images through publication on the activities. Meanwhile, the community that is targeted by the activities receives very little advantage because an effective CSR can only be performed while it is supported by the community's social capital (Yunus 2008; Haris et al. 2015).

Local policies generated by local governments are still in the character of top-down. Its implemention has yet managed to explore the strength of synergy between entrepreneurship and community. Entrepreneurial program and cluster development are still dominated by activities to create technical capacity-building and have yet reached the area of multi-innovation, supply chain management, access to economic resources and opportunities, and profit-sharing system. Local policies have not reflected local genius that is filled with communal strength, meanwhile the two are still very much in existence in agricultural clusters of West Sumatra.

In agricultural clusters of West Sumatra, despite the absence of public policy that fully accommodative to these, the existence of communal entrepreneurship is in fact part to the culture and local genius. Culture is one of the factors that play key roles in entrepreneurship as there are certain cultural values that support the improvement of self potentials of an entrepreneur (Koentjaraningrat 1990). The movement of communal entrepreneurship in agricultural clusters as the synergy between the community and the social entrepreneurship becomes a hope. Social entrepreneurship grows rapidly alongside the conviction that social entrepreneurship can cope with social issues. Social entrepreneurship is achievable by CSR and social business as the form of concern and and business activities where the creation of values is not merely intended to enjoy financial profit but also to contribute into the solution of social, economic, and environmental issues.

\section{CONCLUSIONS}

Put Entrepreneurial policy has yet reached its best in developing SME-based agricultural clusters due to the fact that the entrepreneurial policy of the cluster mainly supports individual and corporate entrepreneurship. The approach is oriented to the interests of some individuals or a group of capital owners and thus, unsuitable to cope with social, economic, and environmental issues in the agricultural clusters. Meanwhile entrepreneurship in agricultural clusters grow as the result of community's synergy and social entrepreneurship or communal entrepreneurship. In reality, communal entrepreneurship contributes to the solution of social, economic, and environmental issues and at the same time, encourages the development of agricultural clusters. Communal entrepreneurship develops agricultural clusters by taking the shape of informal institution based on local genius, and in the shape of formal institution as the representation of communal synergy and social entrepreneurship.

\section{REFERENCES}

Agustino, L., 2008. Dasar-dasar kebijakan publik. Bandung: Alfabeta.

Ahmad, Y., Saad, H. and Yusof, N., 2014. Quality of Life amongst Agropolitan Participant Project: A Malaysian experience. Procedia-Social and Behavioral Sciences, 153, pp.479-490.

Andreopoulou, Z., Tsekouropoulos, G., Theodoridis, A., Samathrakis, V. and Batzios, C., 2014. Consulting for sustainable development, information technologies adoption, marketing and entrepreneurship issues in livestock farms. Procedia Economics and Finance, 9, pp.302-309.

Ashari, A. 2016. Pendirian Bank Pertanian Di Indonesia: Apakah Agenda Mendesak? Analisis Kebijakan Pertanian 8(1):13.

Balabanova, O. N., Rasulya, R. A. and Igor, P. B. 2014. The Modern Methods of Increase of Management Efficiency of Small and Medium Businesses. Life Science Journal 11(11):558-61.

Bappenas. 2004. Tata Cara Perencanaan Pengembangan Kawasan Untuk Percepatan Pembangunan Daerah. Vol. 3.

Baranyi, A., and Krisztina, T. 2015. The Role of SubRegion Heves and Batorterenye in the Economic Development. Journal of Central European Green Innovation 3(1):107-18.

Belousova, O, B., Gaily, and Oliver, B. 2010. A Conceptual Model of Corporate Entrepreneurial Behavior.

BPS. 2013. Laporan Hasil Sensus Pertanian 2013 
(Report of Agricultural Census in 2013). Bps 1-30. BPS. 2018. Hasil Survei Pertanian Antar Sensus. BPS. 2020. Kabupaten Solok Dalam Angka.

Buang, A. and Ratnawati, Y. S. 2009. Pertanian Kontrak Sebagai Satu Kaedah Memajukan Petani Kecil Melayu: Tanggapan Dan Penilaian Komuniti Tani Tempatan Di Zon Utara, Semenanjung Malaysia Terhadap Prestasi Program Pertanian Kontrak FAMA. Geografia : Malaysian Journal of Society and Space 5(1):11-22.

Dahalan, N., Jaafar, M. and Rosdi, S.A.M., 2013. Local community readiness in entrepreneurship: do gender differ in searching business opportunity. Procediasocial and behavioral sciences, 91, pp.403-410.

Darmadji. 2016. Entrepreneurship as New Approach to Support National Agriculture Development Program to Go Self Sufficient Food. Agriculture and Agricultural Science Procedia 9:72-82.

Dhewanto, W., 2013. Inovasi dan Kewirausahaan Sosial. Alfabeta. Bandung.

Dye, T.R. 1992. Understanding public policy. Englewood Cliffs, NJ: Prentice Hall.

Fajzrakhmanov, D.I., Valiev, A.R., Nezhmetdinova, F.T., Nizamov, R.M. and Khamidullin, N.N., 2012. Agrotechnopark as an innovation factor of agriculture competitiveness improving in Russia's WTO entry. Vestnik of Kazan State Agrarian University.

Firdaus, Nur. 2014. Pengentasan Kemiskinan Melalui Pendekatan Kewirausahaan Sosial. Jurnal Ekonomi Dan Pembangunan 22(1):55-67.

Fortunato, M., McLaughlin, D. and Alter, T., 2010. The Individual-Institutional-Opportunity Nexus in Entrepreneurship: Bridging Perspectives in Entrepreneurship and Local Economic Development.

Fortunato, M.W.P. and Alter, T.R., 2016. Culture and entrepreneurial opportunity in high-and lowentrepreneurship rural communities. Journal of Enterprising Communities: People and Places in the Global Economy.

Haris, Z.A., Agustar, A., Noer, M. and Yulnafatmawita, Y., Implementation of Corporate Social Responsibility (CSR) of Cement Factory: Partnership Program, Environmental Guidance, and National CompanyCare. International Journal on Advanced Science, Engineering and Information Technology, 5(6), pp.501-505.

Harpa, E., Moca, S. and Rus, D., 2016. A Comparative Study of Rural Entrepreneurship Romania-Greece. Procedia Technology, 22, pp.1100-1105.

Hassink, J., Hulsink, W. and Grin, J., 2016. Entrepreneurship in agriculture and healthcare: Different entry strategies of care farmers. Journal of Rural Studies, 43, pp.27-39.

Helmi, R. A., Henmaidi, S., and Ibnu, R. A. 2019. Identifying Key Factors Affecting Integrated and Sustainable Development of Red Onion Horticulture
Cluster Area. IJASEIT 9(2):448-54.

Ikatrinasari, Z. F. 2010. Rekayasa Sistem Pendukung Keputusan Intelijen Untuk Pengembangan Agropolitan Berbasis Agroindustri. Pascasarjana Institut Pertanian Bogor.

Jennings, P. D., Royston, G., Michael, D. L., and Roy, S. 2013. Institutions, Entrepreneurs, and Communities: A Special Issue on Entrepreneurship. Journal of Business Venturing 28(1):1-9.

Kitson, M., Ron, M., and Peter, T. 2004. Regional Competitiveness: An Elusive yet Key Concept? Regional Studies 38(9):991-99.

Kuura, A., Robert, A. B., and Rolf, A. L. 2014. Entrepreneurship and Projects-Linking Segregated Communities. Scandinavian Journal of Management 30(2):214-30.

Lowder, S. K., Jakob, S. and Terri, R. 2016. The Number, Size, and Distribution of Farms, Smallholder Farms and Family Farms Worldwide. World Development 87:16-29.

Malek, J. A. 2017. Membangun Pekerja Pengetahuan Di Kawasan Technopole: Merealisasi Permuafakatan Pintar Industri Kecil Dan Sederhana Di BHTV Dan MSC (Developing Knowledge Workers in the Technopole Area : Realizing Smart Collaboration of Small and Medium Industries in BHTV. Geografia Malaysian Journal of Society and Space 8(7):111-24.

Malek, J. A., Abd. Hair, A. and Mohd. Yusof, H. 2009. Pembangunan Pekerja Pengetahuan Di Teknopol Cyberjaya, Malaysia Dan Bengaluru International Tech Park (BITP), India - Satu Perbandingan. Geografia : Malaysian Journal of Society and Space $5(2): 27-44$.

Mandrysz, W. 2020. Community-Based Social Economy - Social Capital and Civic Participation in Social Entrepreneurship and Community Development. Management Dynamics in the Knowledge Economy $8(1): 80-93$.

Mansfeld, R. C., and Jason, A. 2009. Economic Clusters or Cultural Commons? The Limits of CompetitionDriven Development in the Ecuadorian Andes. Latin American Research Review 44(1):132-57.

Martin, R. 2003. A Study on the Factors of Regional Competitiveness: Report for the European Commission DG Regio.

Mirzanti, I. R., Togar, M. S., and Dwi, L. 2015. Mapping on Entrepreneurship Policy in Indonesia. Procedia - Social and Behavioral Sciences 169(August 2014):346-53.

Parwez, S. 2017. Community-Based Entrepreneurship: Evidences from a Retail Case Study. Journal of Innovation and Entrepreneurship 6(1).

Putri, A., Yusmani, Y., Cindy, P., and Zelfi, Z. 2018. Kinerja Faktor Produksi Kopi Arabika (Coffea Arabica L.) Di Lembah Gumanti, Kabupaten Solok, Sumatera Barat. Industria: Jurnal Teknologi Dan Manajemen Agroindustri 7(3):189-97. 
Sefrioui, F. 1999. Industrial Zones Experience in Morocco. Journal of Economic Cooperation among Islamic Countries 20(1):23-70.

Sekliuckiene, J., and Eimantas, K. 2015. Development of Social Entrepreneurship Initiatives: A Theoretical Framework. Procedia - Social and Behavioral Sciences 213:1015-19.

Shane, S., and Sankaran, V. 2000. The Promise of Entrepreneurship as a Field of Research. Academy of Management Review 25(1):217-26.

Soewargo. 2009. Menata Kebijakan Publik Dalam Rangka Demokratisasi Dan Pemerintahan Yang Efektif Dalam Buku Politik Dan Pemerintahan Indonesia. edited by editor Andy Ramses and L. Bakry. Masyarakat Ilmu Pemerintah Indonesia.

Thapa, G. 2010. Smallholder or Family Farming in Transforming Economies of Asia. International Fund for Agricultural Development (IFAD), .

Tohani, E. 2017. Model of the Social Capital Based
Community Entrepreneurship Education (CCE) for Empowering Community: A Initial Theoretical. Advances in Social Science, Education and Humanities Research 118(7):681-86.

Varady, D., Reinout, K., and Maarten, V. H. 2015. Community Entrepreneurship in Deprived Neighbourhoods: Comparing UK Community Enterprises with US Community Development Corporations.

Wibawa, S. 1994. Kebijakan Publik Proses Dan Analisis. Interme.

Yanya, M., Roslan, A. H., and Nor, Azam, A. R. 2013. Does Entrepreneurship Bring an Equal Society and Alleviate Poverty? Evidence from Thailand. Procedia - Social and Behavioral Sciences 91:33140.

Yunus, M. 2008. Creating a World without Poverty: Social Business and the Future of Capitalism. Global Urban Development 4(2):19.

Table 1. Public Policies on Entrepreneurship for Agricultural Cluster Development

\begin{tabular}{|c|c|c|c|c|}
\hline \multirow{2}{*}{ No } & \multirow{2}{*}{ Content } & \multicolumn{2}{|c|}{ Public Policy Level } & \multirow{2}{*}{ Downsides } \\
\hline & & National & Regional & \\
\hline 1 & Agricultural cluster policies & & & \\
\hline $\mathrm{a}$ & $\begin{array}{l}\text { manage strategic location in term of } \\
\text { economic angle. Its consisting of special } \\
\text { economic location; integrated economic } \\
\text { development; trading location and free- } \\
\text { harbour location. Its main objective is } \\
\text { to increase economic growth as well } \\
\text { as decreasing development in-equality. }\end{array}$ & $\begin{array}{l}\text { Regulation number } 26 / 2007 \text { on } \\
\text { location governance }\end{array}$ & $\begin{array}{l}\text { - provincial regulation } \\
\text { number } 13 / 2012 \text { on } \\
\text { regional planning. } \\
\text { - West Sumatra } \\
\text { G o v e } \mathrm{r} \text { o r } \\
\text { decree number } \\
521.305 .2013 \text { on } \\
\text { agricultural cluster } \\
\text { development }\end{array}$ & $\begin{array}{l}\text { The dominant orientation is } \\
\text { economy, while the region } \\
\text { contains social, economic and } \\
\text { cultural conditions. } \\
\text { Regional policy is } \\
\text { dominated by technical and } \\
\text { administrative interests. }\end{array}$ \\
\hline
\end{tabular}

b Farmers protection and empowerment; input supply; business assurance; price risks factor; harvesting failure; climatic condition and high cost economy; access towards information and technology; informal education and extension; developing systemic business, infrastructure of products marketing, institutional capacity building farmers groups; effiency and productivity in processing; value added gain; market coverage and competitive character, capital supply organization to transform farmers position, supply their needs'and trigger entrepreneurship behavior, , tax amnesty and market access

\begin{tabular}{|c|c|c|}
\hline $\begin{array}{l}\text { Regulation number } 19 / 2013 \\
\text { concerning farmers protection } \\
\text { and empower ment } \\
\text { Ministry decree no } 50 / \\
\text { Permentan/CT.140/8/2012 on } \\
\text { cluster approach of developing } \\
\text { agricultural location }\end{array}$ & $\begin{array}{l}\text { Nagari mode } 1 \\
\text { development program } \\
\text { to synergize the } \\
\text { development of } \\
\text { production, marketing, } \\
\text { processing to waste } \\
\text { management. }\end{array}$ & $\begin{array}{l}\text { Entrepreneurship is still } \\
\text { dominated by individuals and } \\
\text { companies. Not yet adopted } \\
\text { entrepreneurship with the } \\
\text { dimension of collective } \\
\text { action. Not yet explained } \\
\text { how the expected synergy } \\
\text { and cooperation will occur. } \\
\text { The regional program is } \\
\text { dominant in improving the } \\
\text { technical skills of farmer } \\
\text { groups (hardskill), }\end{array}$ \\
\hline
\end{tabular}

Regulation number 19/2013 Nagari model Entrepreneurship is still concerning farmers protection development program dominated by individuals and and empower ment to synergize the development of cone dimension of collective how the expected synergy and cooperation will occur. The regional program is technical skills of farmer groups (hardskill), 
2 Entrepreneurial policies

a SMEs empowerment , funding, Regulation number 20/ 2008 partnership and law protection for SMEs. on SMEs

b Entrepreneurship and institutional Presidential decree number capacity building using business 27/2013 on business incubator incubator development.

\section{c}

VOB and Rural economic development

- Regulation number.32/2004 Regultion number 6/ 2014 on village

- Governmental decree number 71/2005.

- Ministry of home affair decree number 39/2010, Ministry of rural development decree number $4 / 2015$ on varieties of VOB activities.

d Policy on social-entrepreneurship CSR

- Regulation number 40/2007 on restricted busness entity
Sijunjung Distric The policy does not include Regulation number the strengthening of marginal ii/2012 on SMEs individuals to be a strong community

Regional policies are still duplicating national policies.

Provincial regulation There is a struggle with other number 9/2000 sectors. Where as regional concerning Nagari or policy is an adjustment to village governance national policy.

- Government decree number 47/2012 on CSR and enviromental consideration

- Regulation number 25/2007 on investment

- Regulation number 22/2001 on oil and gas.

- Regulation number 19/2003 on state-owned enterprise and ministry decree number per-09/ MBU/07/2015.
Provincial regulation number $7 / 2015$ on CSR for enterpries conducting business in West Sumatra 


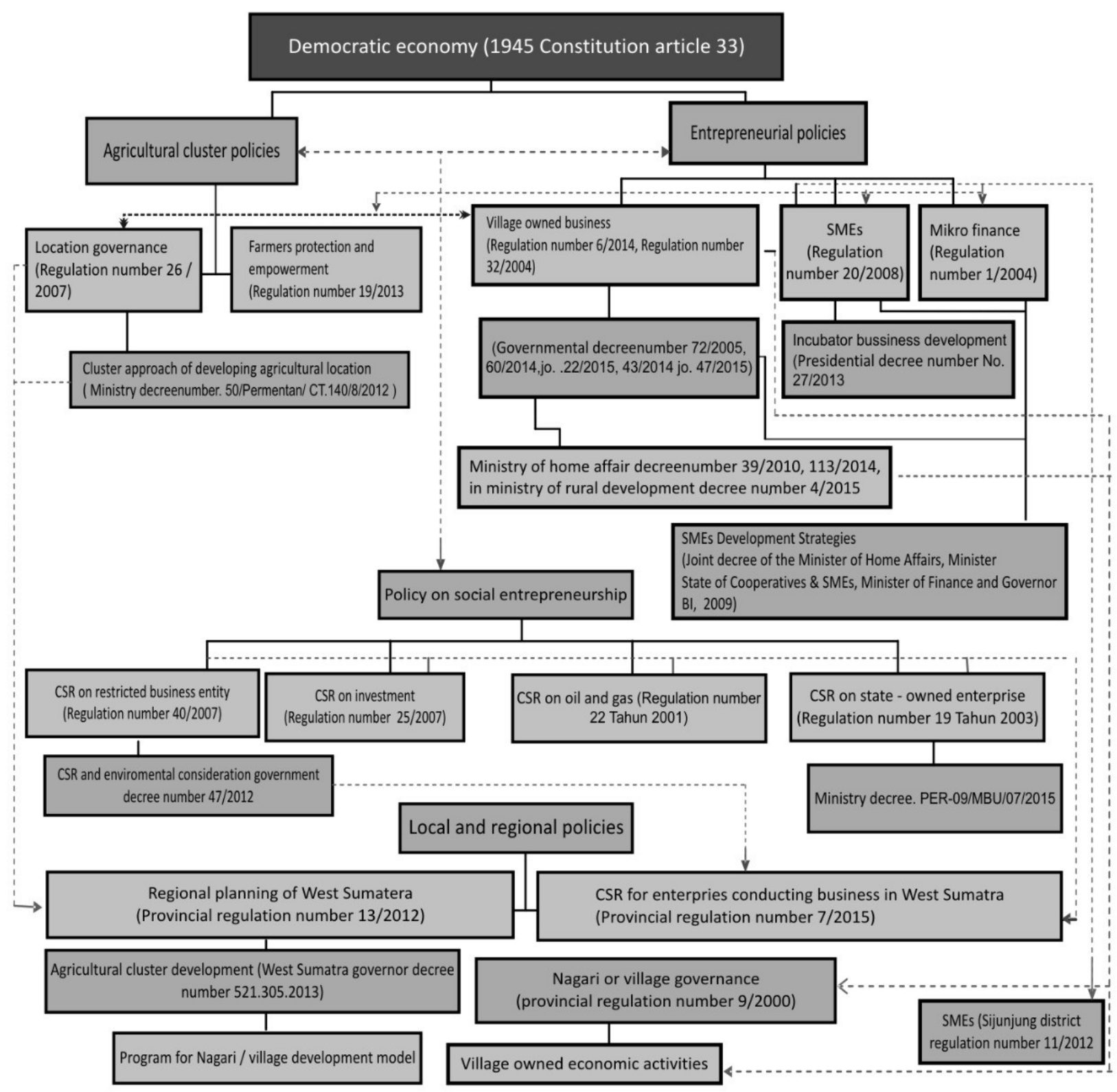

Figure 1. Entrepreneurial Policies in Agricultural Cluster Development Based on SMEs at National and Local Level 